\title{
Diversity of phytoplankton in some domestic wastewater-fed urban fish pond ecosystems of the Chota Nagpur Plateau in Bankura, India
}

\author{
Debjyoti Das $^{1} \cdot$ Arabinda Pathak $^{1} \cdot$ Sudin $\mathrm{Pal}^{2}{ }^{2}$
}

Received: 6 September 2017 / Accepted: 14 May 2018 / Published online: 22 May 2018

(c) The Author(s) 2018

\begin{abstract}
The present limnological investigation is conducted to study the relationship between phytoplankton abundance and five important physicochemical factors in urban wastewater-fed seven fish ponds of Chota Nagpur Plateau area. A total number of 43 phytoplankton taxa representing four classes, namely Cyanophyceae (7), Chlorophyceae (29), Bacillariophyceae (5) and Euglenophyceae (2), are thriving in these ponds which may suggest that different nutrient-rich wastewater supports the diversity and abundance of the phytoplankton. Different values of diversity indices, results of post hoc analysis and rarefaction curve are depicted spatial variations of phytoplankton abundance and physicochemical factors. From the Principal Component Analysis, out of 43 phytoplankton species, 23 important species are extracted. The canonical correspondence analysis presents that most of the phytoplankton species densities are associated with higher values of the physicochemical variables in these ponds. Correspondingly, in the present study, Algal Genus Pollution Index (AGPI) is employed to study the water quality of seven sites. From the AGPI score, it is revealed that Site 4 has probable high organic pollution and Site 2 and Site 3 have moderate organic pollution. Therefore, long-term intensive studies and proper management are necessary to protect these ponds toward eutrophication and degradation, because these ponds not only act as a safeguard of livelihoods but also contribute significantly at local level food and water security and economic prosperity.
\end{abstract}

Keywords Phytoplankton · Physicochemical factors · Diversity indices · Principle component · Post hoc analysis · Canonical correspondence analysis

\section{Introduction}

The information about phytoplankton composition and abundance provides knowledge about the trophic status of wetlands, which will aid to evaluate the possible or optimal usage of them. In an aquatic ecosystem, the base of the food chain is formed by the phytoplankton (Tas and Gonulal 2007; Saravanakumar et al. 2008) and they are responsible for more than $40 \%$ of Earth's photosynthetic production (Schmidt 2000). Therefore, variations in phytoplankton community structure alter the productivity of aquatic system where different organisms exist interdependently. Thus, phytoplankton not only acts as a water quality indicator but

Sudin Pal

sudindgp1@gmail.com

1 Department of Botany, Bankura Sammilani College, Bankura, West Bengal, India

2 Department of Chemical Engineering, Jadavpur University, Kolkata, West Bengal, India also is useful for biomonitoring of lentic freshwater bodies, where multidimensional biological spectrum exists and ecological disturbance caused by alteration of different physicochemical factors (Ponmanickam et al. 2007; Shekhar et al. 2008). These physicochemical factors of aquatic system mostly depend on the discharge of domestic sewage, agricultural runoff water and other anthropogenic activities (Pal et al. 2014).

Several wetland characteristics, which may be spatial, temporal, physical, chemical and biological, have impaction phytoplankton assemblages. Under different irradiance and temperature, algal species show photosynthetic optima (Wehr and Sheath 2003) and species-specific photosynthetic response to light intensity depends on temperature (Wetzel 2001). Moreover, depending upon the temperature the $\mathrm{CO}_{2}$ availability from the water-gas exchange and the bacterial metabolism are affected, resulting in the rate of photosynthesis altered (Prescott 1962). Both $\mathrm{pH}$ and conductivity are correlated with the water carbonate cycle. $\mathrm{pH}$ of an aquatic system mostly depends 
on the presence of carbonate, bicarbonate, carbonic acid, and free $\mathrm{CO}_{2}$ in water (Wetzel 2001). Deviations in $\mathrm{CO}_{2}$ concentration levels due to photosynthesis and respiration can alter the $\mathrm{pH}$ of the water. Also, $\mathrm{CO}_{2}$ uptake by algae increases the $\mathrm{pH}$. It is noted that upon different $\mathrm{pH}$ level, phytoplankton species have a different tolerance range. Phytoplankton assemblage is greatly influenced by $\mathrm{pH}$ in association with the salinity of the water (Sridhar et al. 2006; Saravanakumar et al. 2008). Bacillariophyceae dominates in slightly higher $\mathrm{pH}$ in large lakes in South India (Senthilkumar and Sivakumar 2008), whereas coccal green algae and desmids dominate in high altitude lakes having a less acidic pH (Das and Keshri 2012, 2013). Depending upon the concentration of total dissolved solids (TDS), i.e., an increase in different ions-especially bicarbonates, and carbonates in lake water, increase the electrical conductance (Goswami et al. 2010; Pal et al. 2013, 2018). Wetzel (2001) have considered that phytoplankton diversity is inversely correlated with TDS and conductivity. Badsi et al. (2012) have reported that freshwater phytoplankton adapts to the low salinity. However, depending upon the tolerance level and adaptive capability the pulses of phytoplankton abundance change with the fluctuation of salinity in the freshwater ecosystem.

Further, notwithstanding the chances for competitive exclusion, many species of phytoplankton can coexist owing to their distinctive needs and adaptations. From this, Hutchinson (1961) gives the concept of "paradox of the plankton" and proposes that several niches continually occur in the aquatic ecosystem which allows for phytoplankton diversity. It is not certain that the individual characteristics of an aquatic ecosystem influence community structure, but rather the amalgamation of certain characteristics. Thus, Wetzel (2001) stated that for particular quantification of the relationship with phytoplankton assemblages, a wide variety of characteristics of the aquatic system may not suffice but the associations are valuable for constructing general correlations.

Bankura district is situated in the eastern part of India and is a part of the lower edge of the Chota Nagpur Plateau. The Chota Nagpur Plateau area is internationally famous for coal, bauxite and iron mining. The soil is not fertile enough and of laterite type mixed with sand and rock, red in color. Several ponds and drains are there in this district, but most of them remain dry in the summer. Most of the ponds are used for household purposes and pisciculture practices in monsoon. Furthermost, these ponds receive domestic sewage and depending upon the character and amount of sewage the characteristics of ponds alter. Ali et al. (1999) examined that composite wastewater which contains heavy metals causes the formation of phytoplankton bloom in lakes. Phytoplankton assemblage of water body beside the agricultural field and industrial area in West Bengal, India, is greatly influenced by agricultural and industrial wastes (Ghosh and Keshri 2011; Das et al. 2011, 2015).

Though various studies have indicated the influence of different abiotic factors on phytoplankton communities as a whole (Mukhopadhyay et al. 1997; Chakraborty and Das 2004; Chakraborty et al. 2004; Chattopadhyay and Banerjee 2007), no work has been done yet in this region. Thus, an assessment of phytoplankton community structure and five very important abiotic factors is done to understand the numerous functional properties of phytoplankton species. Moreover, this information can be cast off to assess which, if any, of the factors have an impact on phytoplankton community structure. The five abiotic factors and phytoplankton population structure were tested statistically to define whether any relationships are present. Moreover, due to short life span, easy to quantitative determination and rapid response to pollutants algae act as a bioindicator of water quality changes. Thus, in the present study, the water pollution index (AGPI) is used to detect, if any, organic pollution extant in the water bodies of these areas.

\section{Materials and methods}

\section{Study area}

In the Eastern part of the Chota Nagpur Plateau within Damodar and Darakeswar river basin and in the periphery of Bankura Town, seven study sites were selected for the present study (Fig. 1). This area has undulating landform, interspersed rocky hillocks, laterite soil with slope from west to east. From March to early June due to hot westerly winds, the temperature laid between 37 and $46{ }^{\circ} \mathrm{C}$ and for this reason the little amount of water remains in all water bodies including the rivers also. In the monsoon (July to September), the average rainfall ranged between 1200 and $1400 \mathrm{~mm}$, whereas in dry winter (October to February) the temperature varied between 8 and $20^{\circ} \mathrm{C}$. The domestic sewage-fed seven selected sites were used for pisciculture and household purposes like bathing, washing clothes and kitchen utensils. The location, area and brief description of all sites are presented in Table 1.

\section{Physicochemical analysis of water}

The sampling of the present study was carried out once in a month from January 2017 to July 2017. Water samples were collected in airtight polyvinyl chloride (PVC) bottles. The $\mathrm{pH}$, temperature (TEMP), conductivity (COND), total dissolved solids (TDS) and salinity (SAL) were measured by Eutech PCS Tester-35 Multiparameter testing equipment. 
Fig. 1 Map showing the study sites (Sites 1-7; Google Earth, 2017) nearby Bankura town region (India and West Bengal maps are not in scale.)

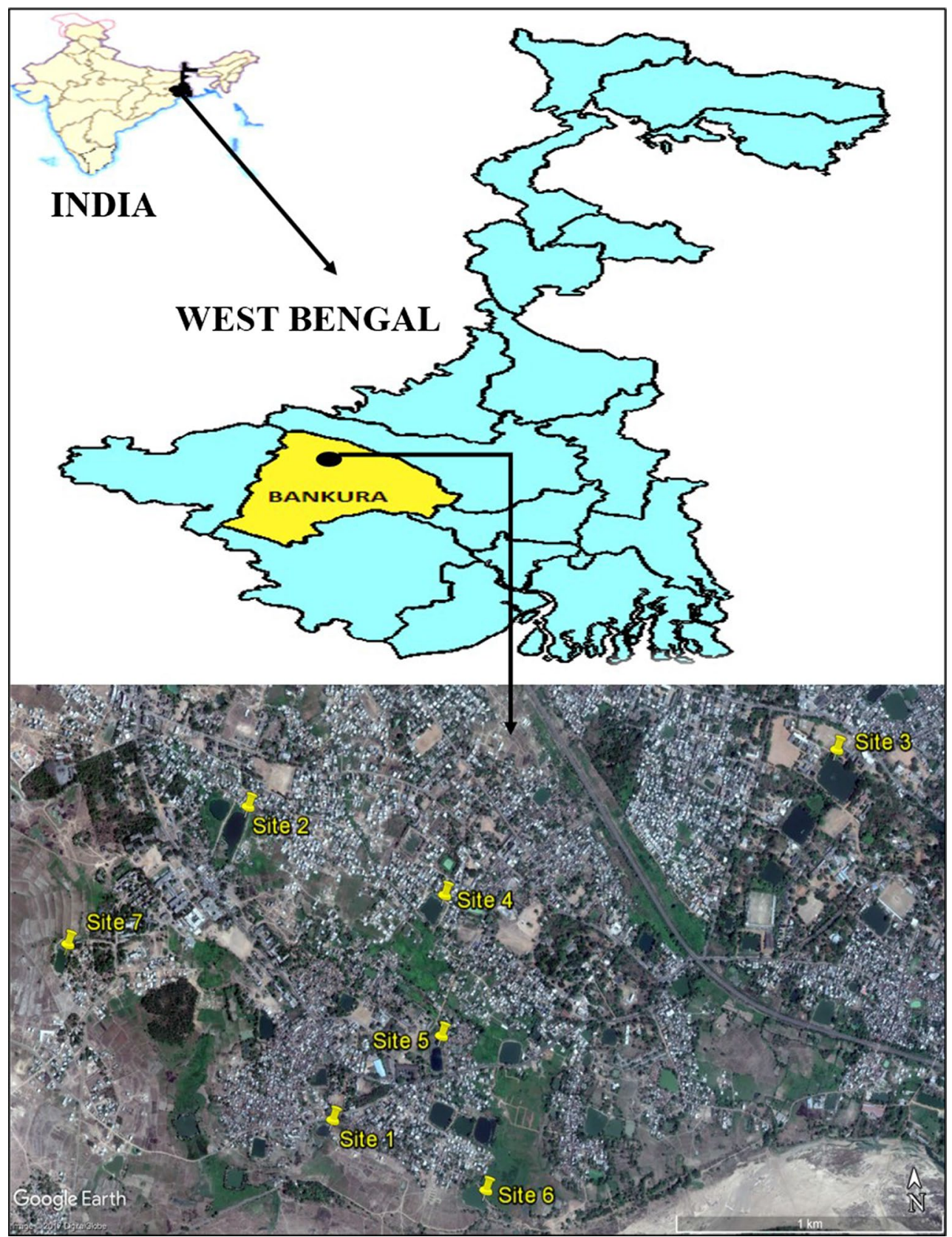

\section{Phytoplankton collection, identification and analysis}

Samples were collected from the different parts of the water bodies. Four samples were collected from each water body per month. One liter of water sample was collected from each collecting point, and 10\% Lugols' Iodine solution was mixed instantly on the spot in 100:1 ratio. All collections were done before $10 \mathrm{am}$ in the morning. Sampling bottles were kept in the laboratory for about $6 \mathrm{~h}$. Then, the $10-\mathrm{mL}$ precipitation was collected from the amber bottle. From the precipitated samples, all workout has been done and $5 \%$ formalin solution was used to preserve it for the future reference. The identification and quantitative analysis of phytoplankton (PHYTO) samples were done by using Carl Zeiss Axiostar microscope with photomicrometry Nikon camera attachment. The phytoplankton was identified by several monographs, viz. Turner (1892), Husted (1930), Desikachary (1959), Prescott (1962) and Philipose (1967).

\section{Statistical analysis}

To show phytoplankton community structure, the diversity indices like Shannon-Wiener diversity index $\left[H^{\prime}\left(\log _{\mathrm{e}}\right)\right]$, Simpson's dominance index $\left(D_{S I P M}\right)$ and Pielou's evenness index $\left(J^{\prime}\right)$ were used. It was noted that the Shannon-Wiener 
Table 1 A brief description of seven selected study sites

\begin{tabular}{|c|c|c|c|}
\hline Sites & Site location & Area (ha) & Description \\
\hline Site 1 & $23^{\circ} 13^{\prime} 35.27^{\prime \prime} \mathrm{N}, 87^{\circ} 2^{\prime} 27.82^{\prime \prime} \mathrm{E}$ & 0.57 & $\begin{array}{l}\text { Over } 20 \% \text { area covered with Eichornia crassipes, Pistia stratiotes, Spirodela polyrhiza and } \\
\text { Wolffia globosa, whereas in the bank, Colocasia esculenta and Polygonum plebeium are } \\
\text { dominated }\end{array}$ \\
\hline Site 2 & $23^{\circ} 14^{\prime} 12.04^{\prime \prime} \mathrm{N}, 87^{\circ} 2^{\prime} 17.71^{\prime \prime} \mathrm{E}$ & 1.44 & $\begin{array}{l}20 \% \text { area covered mostly by } \text { E. crassipes and Salvinia molesta. Also, dense marginal macro- } \\
\text { phytes dominated by Alternanthera sessilis, Commelina bengalensis, and Eclipta alba are } \\
\text { present }\end{array}$ \\
\hline Site 3 & $23^{\circ} 14^{\prime} 16.40^{\prime \prime} \mathrm{N}, 87^{\circ} 3^{\prime} 34.66^{\prime \prime} \mathrm{E}$ & 2.14 & $\begin{array}{l}70 \% \text { of the bank is concreted. Rest of the bank area wetland macrophytes like } C \text {. esculenta, } P \text {. } \\
\text { plebeium, A. sessilis, } C \text {. bengalensis are present. A little amount of E. crassipes, P. strati- } \\
\text { otes present in open water }\end{array}$ \\
\hline Site 4 & $23^{\circ} 14^{\prime} 0.00^{\prime \prime} \mathrm{N}, 87^{\circ} 2^{\prime} 43.00^{\prime \prime} \mathrm{E}$ & 0.92 & $\begin{array}{l}\text { Water body with a dense Azolla pinnata on surface water and Najas graminea, Hydrilla } \\
\text { verticillatain under water. A. sessilis, P. plebeium, and Ipomoea aquaica are mostly present } \\
\text { in bank region }\end{array}$ \\
\hline Site 5 & $23^{\circ} 13^{\prime} 45.00^{\prime \prime} \mathrm{N}, 87^{\circ} 2^{\prime} 42.00^{\prime \prime} \mathrm{E}$ & 1.19 & $\begin{array}{l}\text { Dominated by E. crassipes, Lemna minor, P. barbatum, S. polyrhiza over the } 40 \% \text { of the sur- } \\
\text { face water. In the bank, the dominated macrophytes are I. aquaica, A. sessilis, C. bengha- } \\
\text { lensis, Centella asiatica }\end{array}$ \\
\hline Site 6 & $23^{\circ} 13^{\prime} 26.64^{\prime \prime} \mathrm{N}, 87^{\circ} 2^{\prime} 47.90^{\prime \prime} \mathrm{E}$ & 0.81 & $\begin{array}{l}\text { Clear surface water and presence of Ceratophyllum demersum in under water and Marsilea } \\
\text { minuta, C. benghalensis, I. aquaica are present in the bank }\end{array}$ \\
\hline Site 7 & $23^{\circ} 13^{\prime} 56.99^{\prime \prime} \mathrm{N}, 87^{\circ} 1^{\prime} 54.03^{\prime \prime} \mathrm{E}$ & 0.52 & $\begin{array}{l}\text { Dominated by Nymphoides hydrophylla. In bank region, dense mat Hygrophila spinosa, } \\
\text { Marsilea minuta is observed }\end{array}$ \\
\hline
\end{tabular}

diversity index was more subtle to rare species and Simpson's index gave more prominence to common species, while Pielou's index gave the indication about the species homogeneity (Adhikari et al. 2017). Beta diversity was measured to know about the differences in species composition among the study sites. Spatially constrained individual-based rarefaction was used to estimate the species richness that was directly comparable to the areas that differed in spatial extent. All these analyses were calculated by using PAST (version 3.15, 2017) software.

In any ecosystem, the physicochemical factors influence the biotic interactions and in most cases, univariate analyses were inadequate to assess interactions. Thus, multivariate analyses were practically used to understand the role of physicochemical factors in influencing biotic community from different ecosystems. Here the selection of methods for statistical analyses was done following Quinn and Keough (2002). Principal component analysis (PCA) was executed with Kaiser normalization, and Varimax rotation was used as a dimension-reducing technique and to comment on the group or groups of important phytoplankton species in those study sites. Forty-three phytoplankton species of seven study sites were subjected to PCA to reduce the number of dimensions. Here first three components of PCA were taken into consideration, and factor loadings $(\mathrm{FL})>0.7$ at any component were considered to be significant. Canonical correspondence analysis (CCA) was used to evaluate the relationship, if any, between abiotic factors and phytoplankton abundance of seven study sites. Twenty-three phytoplankton species were shortlisted (based on PCA) from 7 study sites, in order to evaluate how different community was structured by their environmental characteristic. The significance of the CCA axes and respective environment variables was evaluated by the Monte Carlo tests with 999 unrestricted permutations (TerBraak and Prentice, 1988). Post hoc analysis was performed to know about the significant difference in abiotic factors and phytoplankton abundance within each site. The two-dimensional hierarchical cluster analyses were known as dendrogram, and by linkage methods, this dendrogram was constructed. In this method, groups were fused according to the distance between their nearest members. Thus, to show the affinity between study sites, the dendrograms were constructed based on abiotic factors and phytoplankton abundance. Statistical analyses were performed using Statistica for Windows 8.0 (StatSoft Inc. 2007) software and PAST (version 3.15, 2017) software. The Graphs were prepared by using Origin Pro 2016.

\section{Results and discussion}

Overall, 43 phytoplankton species are identified, of which 7 species belong to the class Cyanophyceae, 14 belongs to class Chlorophyceae, and 5 belongs to class Bacillariophyceae and 2 species of Euglenophyceae. The abundance of Oscillatoria limosa is the highest in Site 1, Site 3 and Site 6, while Chlorella vulgaris in Site 2, Merismopedia minima, Anabaena circinalis in Site 5, Spirogyra maxima in Site 7 are most abundant. It is noted that under the family Euglenophyceae two species like Euglena acus and Phacus acuminatus are only observed at Site 4 ("Appendix 1"). Considering all sites the percentage contribution of Chlorophyceae is the 
highest trailed by Cyanophyceae and Bacillariophyceae. The same trends are followed in sitewise calculation except Site 3 and Site 4 where Cyanophyceae is more abundant than Chlorophyceae (Fig. 2). The trend of phytoplankton density (number $\mathrm{mL}^{-1}$ ) is Site $4>$ Site $5>$ Site $3>$ Site $1>$ Site $7>$ Site $6>$ Site 2 , while Site $4>$ Site $5>$ Site $7>$ Site
$3>$ Site $2>$ Site $6>$ Site 1 is the trend of number of phytoplankton species assemblage. The hierarchical cluster analysis (Single Linkage Euclidean Distance) of this study based on phytoplankton abundance placed Site 2, Site 3, Site 6 and Site 7 in a close cluster, and Site 1 and Site 5 were distantly clustered with them, whereas Site 4 is an out group (Fig. 3a).

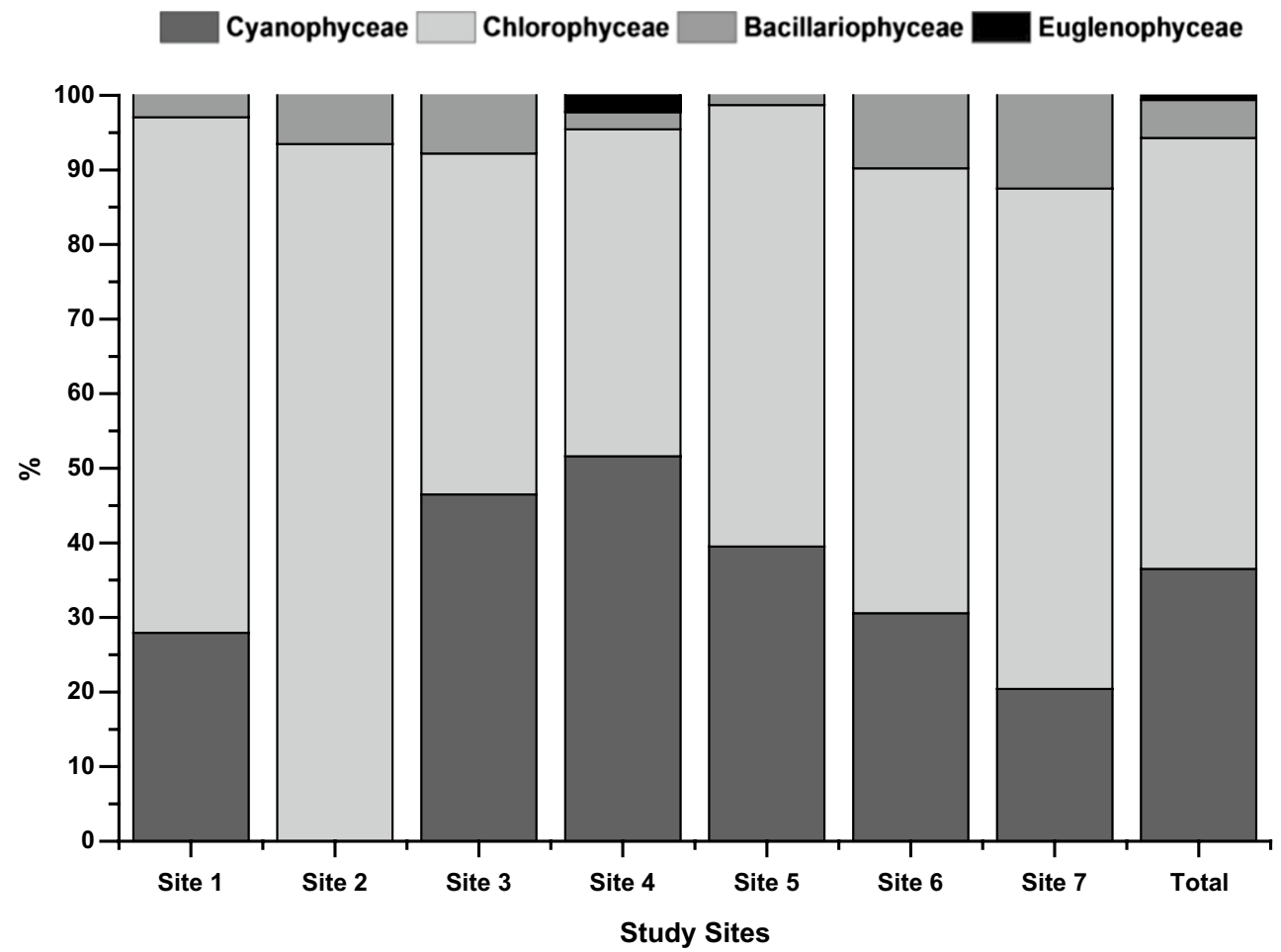

Fig. 2 Percentage distribution of Phytoplankton families in each site and altogether seven sites
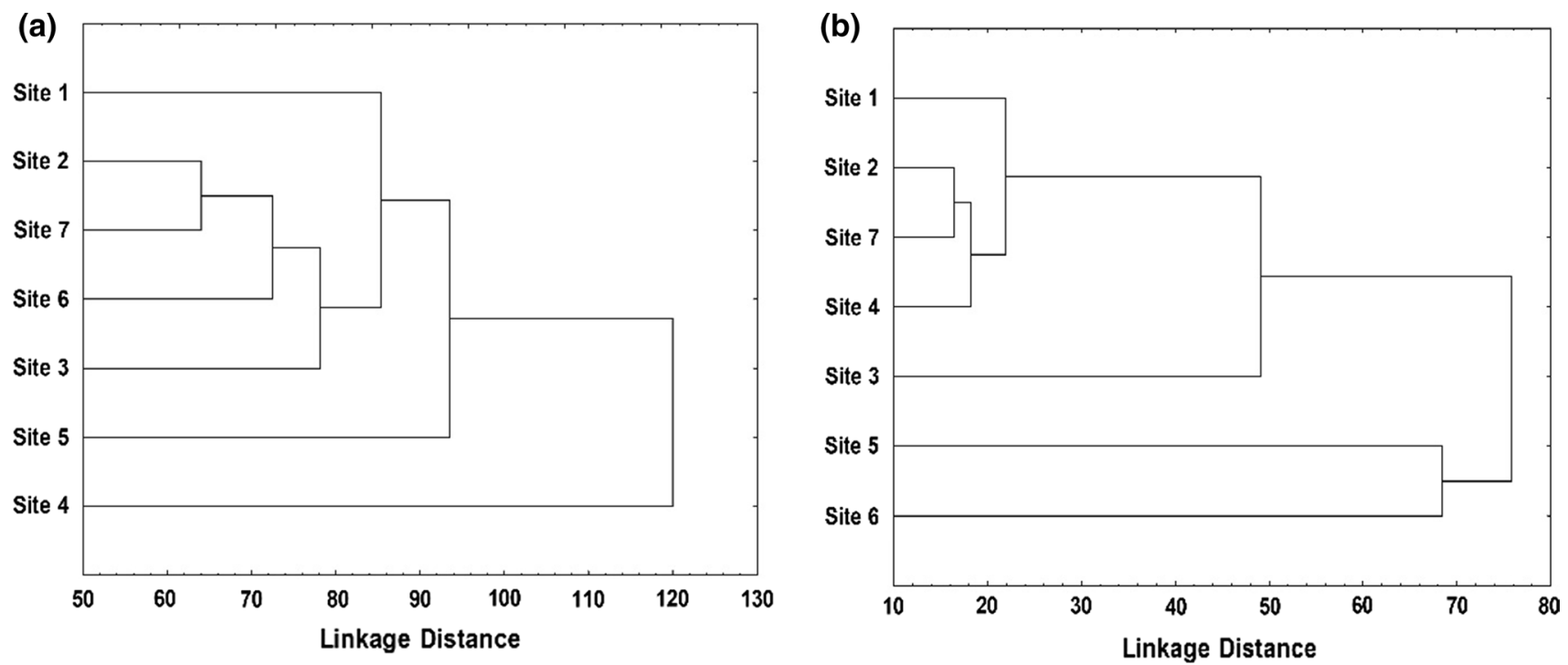

Fig. 3 Hierarchical cluster analysis (single linkage Euclidean distances) of seven different sites depending on phytoplankton assemblage (a) and physicochemical factors $(\mathbf{b})$ 
Table 2 Spatial changes in diversity indices: ShannonWiener general diversity index $H^{\prime}\left(\log _{e}\right)$, Simpson's dominance index $\left(D_{S I P M}\right)$ and Pielou's evenness index $\left(J^{\prime}\right)$

\begin{tabular}{llll}
\hline & $H^{\prime}\left(\log _{e}\right)$ & $D_{\text {SIMP }}$ & $J^{\prime}$ \\
\hline Site 1 & 1.546 & 0.770 & 0.782 \\
Site 2 & 2.014 & 0.835 & 0.749 \\
Site 3 & 2.113 & 0.846 & 0.689 \\
Site 4 & 2.541 & 0.903 & 0.705 \\
Site 5 & 2.259 & 0.861 & 0.684 \\
Site 6 & 1.690 & 0.788 & 0.774 \\
Site 7 & 2.390 & 0.899 & 0.839 \\
\hline
\end{tabular}

That means the phytoplankton species composition of Site 4 is different from all other sites.

Sitewise values of diversity indices, viz. Shannon-Wiener diversity index $\left[H^{\prime}\left(\log _{\mathrm{e}}\right)\right]$, Simpson's dominance index $\left(D_{S I P M}\right)$ and Pielou's evenness index $\left(J^{\prime}\right)$, are depicted in Table 2 . The species diversity $H^{\prime}\left(\log _{\mathrm{e}}\right)$ and $D_{\text {SIPM }}$ values are high in Site 4, Site 5, Site 7 and Site 3 and low at Site 1 and Site 2. But except Site 7, J' showed a reverse trend. It is noted that $H^{\prime}\left(\log _{\mathrm{e}}\right)$ is more sensitive to rare species, whereas $D_{\text {SIPM }}$ gives importance to the common species. That means here in Site 4, Site 5, Site 7 and Site 3 high phytoplankton diversity reflects the dominance of common phytoplankton species, while the opposite phenomenon is shown in Site 1 and Site 2. However, low values of species dominance reflect high evenness of species distribution. In the present study due to high $J^{\prime}$ values in Site 1, Site 2 and Site 6 cause low $D_{S I P M}$ values. However, due to the difference in species abundance and composition, the value of beta diversity (Bw) of Site 1 is different with Site 3, Site 4, Site 5 and Site 6, while very similar with Site 2 and Site 7(Table 3). However, except Site 1, the species composition of Site 2 is highly similar to other sites. Site 3 is more similar with Site 5 than Site 4 and Site 7, while with Site 6 low similarity is found. Though the values of $H^{\prime}\left(\log _{\mathrm{e}}\right)$ and $D_{S I P M}$ of Site 7 are very close to Site 3 , Site 4 , Site 5 and Site 6 , the lower similarity of species composition is noticed from the $\mathrm{Bw}$ values. The individualbased spatially constrained rarefaction curve gives more idea about species richness of samples that differ in the area and sampling effort (Chiarucci et al. 2009). Though the overall diversity of seven sites does not differ much, the species accumulation curves are constructed, which calculated the expected number of species in a subsample drawn randomly from a single representative sample from an assemblage (Fig. 4). The individual-based rarefaction curves amply pointed out that Site 4 followed by Site 5 and Site 3 has higher species richness than other sites, and this result corroborates with the Bw values. However, the post hoc analysis (Tukey's HSD) gives better understanding regarding spatial differences in phytoplankton assemblages at $p<0.05$ level (Fig. 5).
Table 3 Whittaker beta diversity $\left(B_{w}\right)$ within seven study sites

\begin{tabular}{lllllll}
\hline & Site 1 & & & & \\
Site 2 & 1.00 & Site 2 & & & \\
Site 3 & 0.67 & 0.91 & Site 3 & & \\
Site 4 & 0.75 & 0.93 & 0.73 & Site 4 & & \\
Site 5 & 0.60 & 0.83 & 0.85 & 0.63 & Site 5 & \\
Site 6 & 0.69 & 0.88 & 0.58 & 0.76 & 0.81 & Site 6 \\
Site 7 & 1.00 & 0.74 & 0.76 & 0.81 & 0.78 & 0.700 \\
\hline
\end{tabular}

Fig. 4 Individual-based rarefaction curves calculated on the basis of seven study sites under study

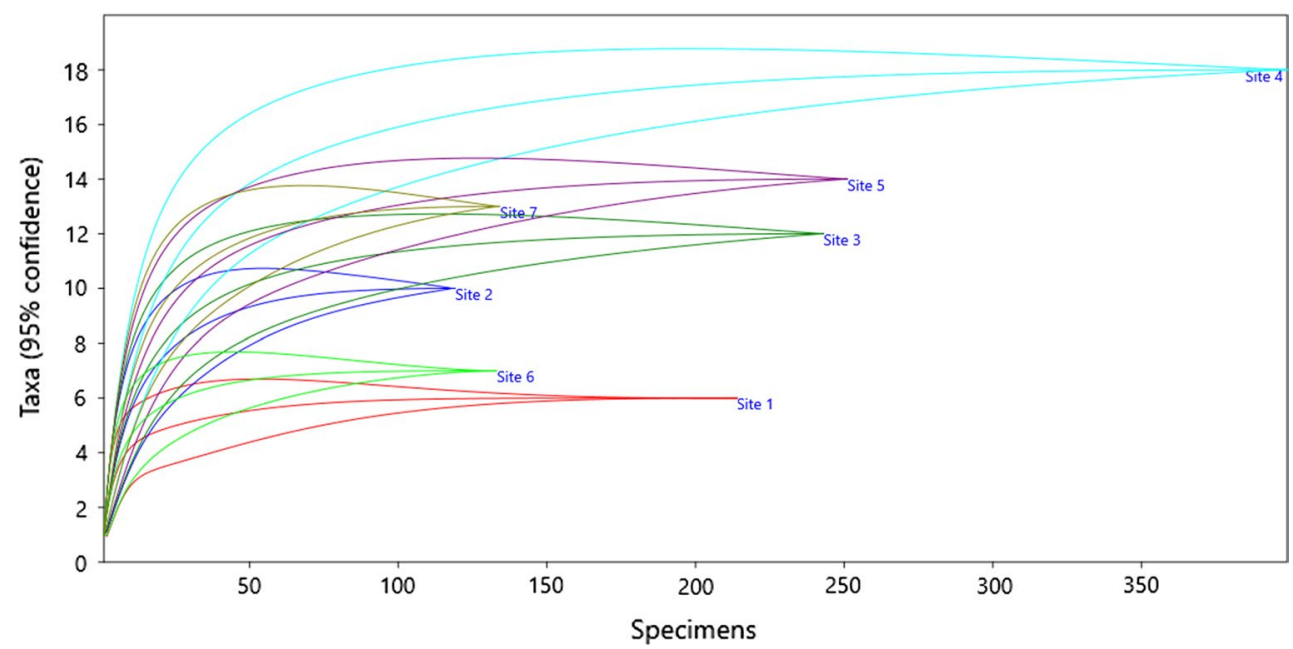

مدينة الملك عبدالعزيز

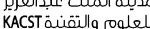



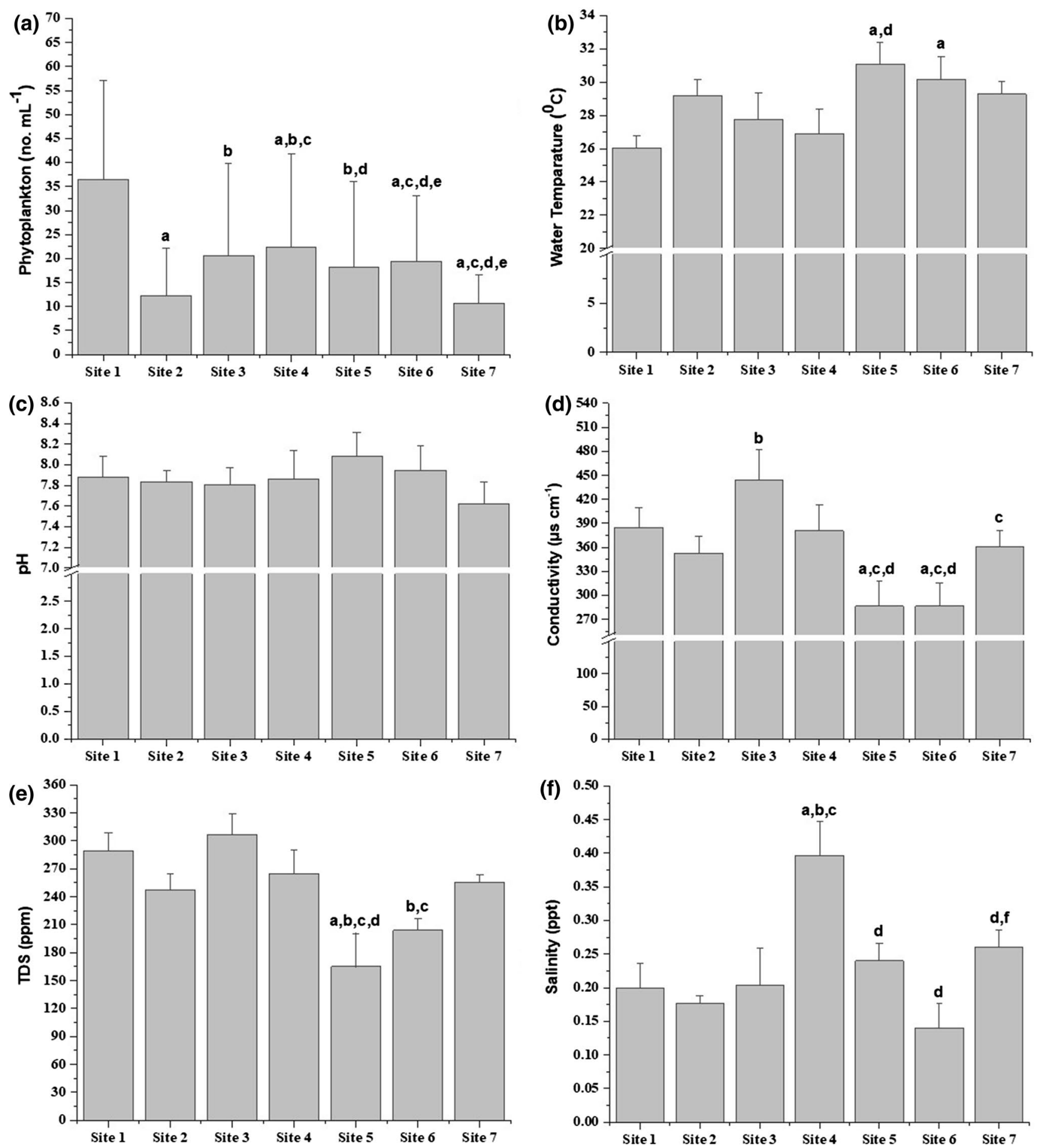

Fig. 5 Phytoplankton assemblage and physicochemical factors at seven selected study sites. By using post hoc analysis (Tukey's HSD), the site which differs significantly $(p<0.05)$ with others sites, marked as follows: a Site 1, b Site 2, c Site 3, d Site 4, e Site 5, f Site 6

It is very important to monitor physicochemical factors in the aquatic system for better understanding about their influences on the distribution of aquatic diversity (Das et al. 2012, 2015). In the present study, the five most important physicochemical factors are assessed and sitewise graphically represented in Fig. 5. The mean water temperature (WT), which is an important factor to control aquatic life, varies between 25 and $31{ }^{\circ} \mathrm{C}$ from different sites. Significant spatial differences in WT $(p<0.05)$ are noted between Site 1 and Site 5, Site 6 and Site 4 with Site 5. Though 
the recorded temperature range is good for plankton growth (Wassie and Melese 2017), it can be noted that increase of $1{ }^{\circ} \mathrm{C}$ WT increases the ionic mobility and solubility of salts, which proliferate conductivity 2-4\% (Miller et al. 1988) and effects on phytoplankton assemblage. The water $\mathrm{pH}$ is slightly basic, i.e., 7.5-8, in seven study sites, and this $\mathrm{pH}$ range not only is better for phytoplankton but also is healthy for aquatic life including fish and fall (Oso and Fagbuaro 2008). TDS is the sum of all ion particles smaller than 2 microns, and its value beyond the safe limit of $500 \mathrm{ppm}$ (Hem 1985; EPA 2012) causes the cell to swell or shrink and affect aquatic organism to move in the water column. The TDS of all the sites, which is mostly contributed by the domestic sewage, lies between 136 and 303 ppm, and these values are very conductive for the aquatic life (Mohamed et al. 2009). The conductivity (COND) is a measure of a solution's conductive abilities that affect the ecological feasibility of shallow freshwater ponds, viz. the present study sites. Actually COND is a primary indicator of alteration in aquatic system and it depends on natural flooding, evaporation and pollution load. It is noted that an increase in water COND decreases the phosphorus availability to the phytoplankton that results in decline of phytoplankton populations (Chouyyok et al. 2010; López-Flores et al. 2014). The average COND in seven sites is $272-431 \mu \mathrm{S} \mathrm{cm}^{-1}$ which is lower than safe limits $\left(2000 \mu \mathrm{S} \mathrm{cm}^{-1}\right)$ of freshwater lakes criteria
(Kemker 2015), and it indicates healthy pond ecosystem. Significant spatial differences $(p<0.05)$ for both TDS and COND are shown same for Site 1 with Site 5 and Site 6; Site 3 with Site 5 and Site 6; Site 4 with Site 5. Except these, the TDS of Site 2 significantly differs with Site 5 and Site 5 with Site 7; likewise COND of Site 2 significantly differ with Site 3, Site 3 with Site 7 and Site 4 with Site 6. Nielsen et al. (2003) has suggested that salinity of freshwater lakes above 1ppt creates adverse effect on aquatic biota; especially some studies (Redden and Rukminasari 2008; Flöder et al. 2010; Larson and Belovsky 2013) indicate that high salinity in aquatic system can decrease phytoplankton concentration as well as it affects the species composition. But here in the seven sites, the salinity ranges from 0.13 to $0.39 \mathrm{ppt}$, which is required to maintain physiological process as well as the growth of the phytoplankton. Post hoc analysis at $p<0.05$ shows that the salinity levels of Site 4 were significantly different with other six sites, and it may be due to higher sewage input in Site 4 than other sites (Fig. 5). It is also revealed from the present study that by mixing of domestic sewage and agricultural runoff, which contains numerous luxuriant nutrients and different salts of sodium, potassium, calcium, and magnesium, presently maintained the favorable condition for phytoplankton production (Fig. 6).

The species dynamics of phytoplankton have changed with the alteration of physicochemical factors. Each species

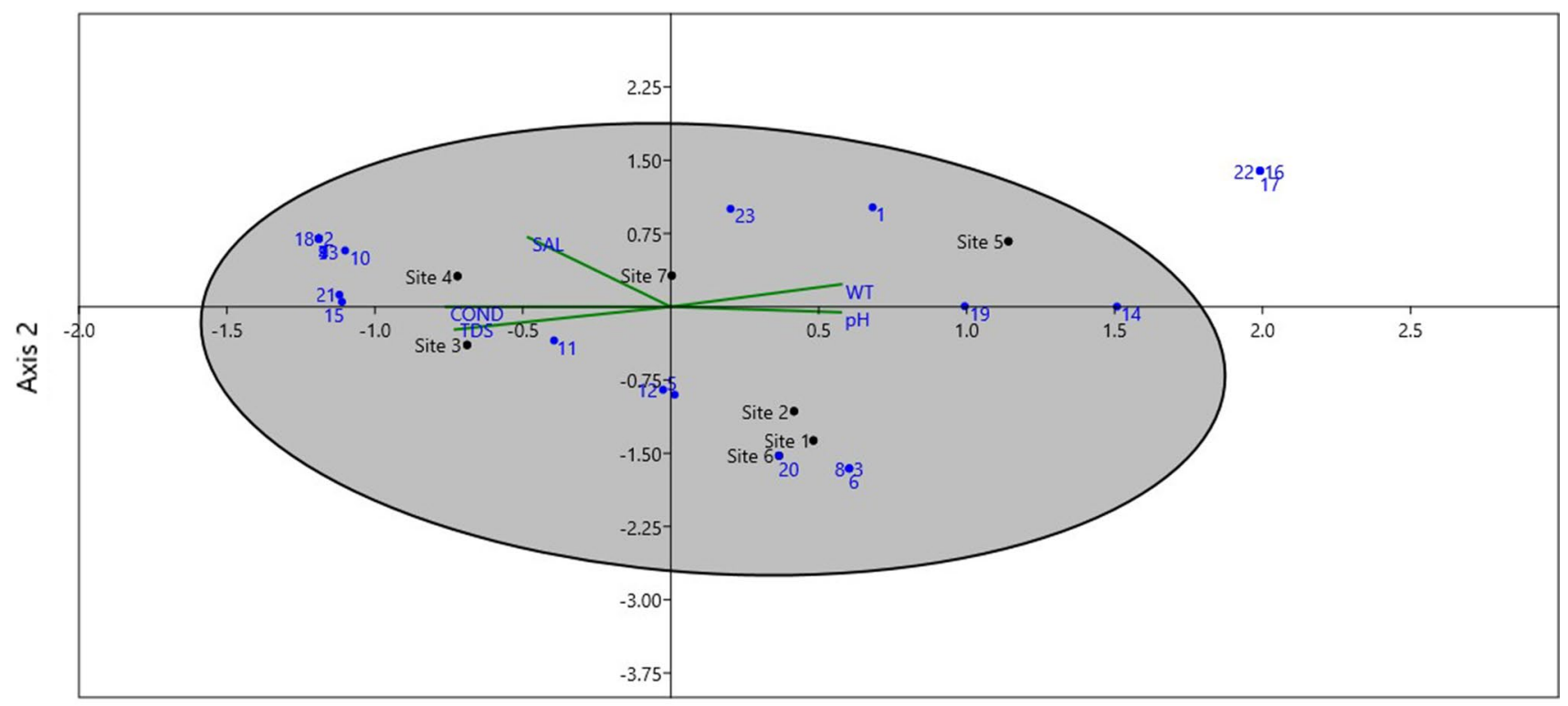

Axis 1

Fig. 6 Canonical correspondence analysis (CCA) ordination diagram showing scatter plot for selected phytoplankton, environmental variables and seven study sites. Vector lines represent the relationship of significant environmental variables to the ordination axes; their length is proportional to their relative significance. ( $1=$ Anabaena circinalis, $2=$ Ankistrodesmus falcatus, $3=$ Chlorella vulgaris, $4=$ Chroococcus limneticus, $5=$ Closterium parvulum, $6=$ Dimorpho- coccus lunatus, $7=$ Euglena acus, $8=$ Eunotia pectinalis, $9=$ Gonium pectorale, 10=Merismopedia minima, 11=Mougeotia punctata, $12=$ Nitella mucronata, $13=$ Oocystis elliptica, $14=$ Oocystis pusilla, 15=Oscillatoria major, 16=Pediastrum duplex, 17=Pediastrum tetras, 18=Phacus acuminatus, 19=Scenedesmus obliquus, $20=$ Spirogyra gracilis, $21=$ Spirogyra weberi, $22=$ Spirulina major, $23=$ Tetraedron trigonum) 
respond differently to the environmental factors. So, to find out this relationship different canonical correspondence analysis (CCA) is done. But, before that, the factor analysis is performed to identify the principle component within the long list of phytoplankton at seven study sites in the Chota Nagpur Plateau. The significant presence of phytoplankton is recognized depending upon factor loadings (FL) $>0.7$ of the first three components that explained $68.26 \%$ of phytoplankton species and out of a total of 43 species of phytoplankton only 23 phytoplankton species are shortlisted as significant species (Table 4). Within this 23 phytoplankton species, 5 are from Cyanophyceae, 17 from Chlorophyceae, only 1 from Bacillariophyceae and no representation of Euglenophyceae found.

Canonical correspondence analysis (CCA) exhibits that the densities of most of the phytoplankton species are associated with higher values of the physicochemical variables. The result of the test of significance using the Monte Carlo test on CCA to highlight the phytoplankton species-environmental variable relations is depicted in Table 5. The eigenvalues and the percentages of variance in axis 1 are found to be higher than axis 2 , which corroborates the findings of Liu et al. (2010) and Sharma et al. (2016). Between physicochemical factors and phytoplankton species, the eigenvalue for axis 1 (0.5550) explains $38.47 \%$ correlation, while axis 2 (0.416) explicates $29.06 \%$ correlation. A. circinalis, $O$. pusilla, $P$. duplex, $P$. tetras, $S$. obliquus and $S$. major indicate that they are positively correlated with the higher value of WT and $\mathrm{pH}$. The TDS and COND are positively correlated with each other (Pal et al. 2013; Das et al. 2015), and with them $O$. major, $S$. weberi has a positive relationship. The distribution of A. falcatus, C. limneticus, E. acus, G. pectoral, M. minima, O. elliptica, $P$. acuminatus is found to be positively dependant on salinity. However, some phytoplankton species, viz. Chlorella vulgaris, Closterium parvalum, Dimorphococcus lunatus, Eunotia pectinalis, Nitella mucronata are found to be least affected by the variation of measured physicochemical factors.

\section{Conclusion}

The physicochemical and biological characters change in the lentic ecosystem due to the discharge of wastes, which increase the concentration of different chemicals (Roy Goswami et al. 2011, 2013; Pal et al. 2014). From the present study, it is apparent that a respectable number of phytoplankton species thrived in these wastewater-fed ponds, when added to these ponds harbor different floating and marginal macrophytes. That means this urban wastewater, which contained several nutrients, not only enriches the phytoplankton diversity and abundances in these ponds but also is helpful for pisciculture practices
Table 4 Factor loadings of phytoplankton species from seven different sites

\begin{tabular}{|c|c|c|c|}
\hline Phytoplankton species & PC 1 & PC 2 & PC 3 \\
\hline Anabaena circinalis & -0.283 & 0.816 & 0.258 \\
\hline Ankistrodesmus falcatus & -0.984 & 0.014 & 0.075 \\
\hline Aulosira implexa & -0.646 & 0.654 & 0.250 \\
\hline Bulbochaete satigera & 0.293 & -0.233 & -0.182 \\
\hline Chara braunii & 0.319 & -0.348 & -0.044 \\
\hline Chlorella vulgaris & 0.039 & 0.087 & -0.908 \\
\hline Chroococcus limneticus & -0.984 & 0.014 & 0.075 \\
\hline Cladophora glomerata & -0.338 & 0.015 & 0.368 \\
\hline Closterium parvulum & 0.245 & -0.098 & -0.877 \\
\hline Closterium ehrenbergii & 0.145 & -0.528 & 0.335 \\
\hline Coelastrum microporum & 0.237 & 0.439 & 0.457 \\
\hline Coleochaete islamii & 0.397 & 0.411 & 0.024 \\
\hline Cymbella acuta & 0.349 & -0.559 & 0.072 \\
\hline Desmidium baileii & 0.145 & -0.528 & 0.335 \\
\hline Dimorphococcus lunatus & 0.039 & 0.087 & -0.908 \\
\hline Euglena acus & -0.984 & 0.014 & 0.075 \\
\hline Eunotia pectinalis & 0.039 & 0.087 & -0.908 \\
\hline Gonium pectorale & -0.984 & 0.014 & 0.075 \\
\hline Hyalotheca dissiliens & 0.145 & -0.528 & 0.335 \\
\hline Merismopedia minima & -0.938 & -0.033 & 0.039 \\
\hline Mougeotia punctata & -0.814 & 0.071 & -0.554 \\
\hline Nitella mucronata & 0.258 & -0.113 & -0.844 \\
\hline Nitzschia amphibia & -0.107 & -0.294 & 0.053 \\
\hline Nitzschia sigma & 0.198 & -0.303 & -0.625 \\
\hline Oedogonium fragile & 0.404 & -0.532 & 0.016 \\
\hline Oedogonium aquaticum & 0.293 & -0.233 & -0.182 \\
\hline Oocystis elliptica & -0.984 & 0.014 & 0.075 \\
\hline Oocystis pusilla & 0.263 & 0.879 & 0.380 \\
\hline Oscillatoria limosa & 0.296 & -0.549 & 0.565 \\
\hline Oscillatoria major & -0.766 & -0.332 & 0.285 \\
\hline Pediastrum duplex & 0.215 & 0.879 & 0.258 \\
\hline Pediastrum tetras & 0.215 & 0.879 & 0.258 \\
\hline Phacus acuminatus & -0.984 & 0.014 & 0.075 \\
\hline Pleurotaenium trabecula & 0.186 & 0.698 & -0.570 \\
\hline Rhizoclonium lapponicum & -0.310 & 0.132 & 0.214 \\
\hline Scenedesmus bijugatus & 0.039 & 0.087 & -0.908 \\
\hline Scenedesmus obliquus & 0.320 & 0.744 & -0.490 \\
\hline Spirogyra gracilis & -0.141 & 0.033 & 0.792 \\
\hline Spirogyra weberi & -0.828 & -0.286 & 0.259 \\
\hline Spirogyra maxima & 0.314 & -0.616 & 0.182 \\
\hline Spirulina major & 0.215 & 0.879 & 0.258 \\
\hline Synedra acus & -0.465 & 0.056 & 0.670 \\
\hline Tetraedron trigonum & -0.704 & 0.602 & 0.238 \\
\hline Eigenvalue & 12.608 & 8.772 & 7.972 \\
\hline Cumulative $\%$ & 29.321 & 49.721 & 68.262 \\
\hline
\end{tabular}

Average extraction: principal components with Kaiser normalization. Factor loadings $>0.7$ in each component were considered as significant and are marked with bold faces 
Table 5 Monte Carlo test of canonical correspondence analysis (CCA) using overall mean values to indicate phytoplankton-environment relationship at selected study sites

Table 6 Pollution index of algal genera according to Palmer (1969) at seven study sites

\begin{tabular}{|c|c|c|c|c|c|}
\hline Axes & 1 & 2 & 3 & 4 & Total inertia \\
\hline Eigenvalues & 0.550 & 0.416 & 0.292 & 0.173 & 1.431 \\
\hline $\begin{array}{l}\text { Cumulative percentage variance of } \\
\text { species-environment relation }\end{array}$ & 38.47 & 67.53 & 87.91 & 100.0 & \\
\hline \multicolumn{6}{|c|}{ Summary of Monte Carlo test (999 permutations under reduced model) } \\
\hline \multicolumn{6}{|c|}{ Test of significance of first canonical axis: eigenvalue $=0.550$} \\
\hline \multicolumn{6}{|l|}{$p$ value $=0.006$} \\
\hline \multicolumn{6}{|c|}{ Test of significance of all canonical axes: trace $=1.431$} \\
\hline \multicolumn{6}{|c|}{$p$ value $=0.001$} \\
\hline
\end{tabular}

\begin{tabular}{|c|c|c|c|c|c|c|c|c|}
\hline Algal Genus & Pollution index & Site 1 & Site 2 & Site 3 & Site 4 & Site 5 & Site 6 & Site 7 \\
\hline \multicolumn{9}{|l|}{ Cyanophyceae } \\
\hline Oscillatoria & 5 & 5 & - & 5 & 5 & - & 5 & - \\
\hline \multicolumn{9}{|l|}{ Chlorophyceae } \\
\hline Ankistrodesmus & 2 & 2 & - & - & 2 & - & - & - \\
\hline Chlorella & 3 & - & 3 & - & - & - & - & - \\
\hline Closterium & 1 & - & 1 & 1 & - & - & - & 1 \\
\hline Scenedesmus & 4 & - & 4 & - & - & 4 & - & 4 \\
\hline \multicolumn{9}{|l|}{ Bacillariophyceae } \\
\hline Nitzschia & 3 & - & 3 & 3 & 3 & - & 3 & 3 \\
\hline Synedra & 2 & 2 & - & 2 & 2 & 2 & - & - \\
\hline \multicolumn{9}{|l|}{ Euglenophyceae } \\
\hline Euglena & 5 & - & - & - & 5 & - & - & - \\
\hline Phacus & 2 & - & - & - & 2 & - & - & - \\
\hline Total score & & 9 & 11 & 11 & 19 & 6 & 8 & 8 \\
\hline
\end{tabular}

Following numerical values for pollution classification: $0-10=$ lack of organic pollution; $10-15=$ moderate pollution; $15-20=$ probable high organic pollution; 20 or more $=$ high organic pollution and it will surely improve the local economy. Also as per Palmer's (1969) Algal Genus Pollution Index (Table 6), it is revealed from the present study that Site 4 has probable high organic pollution, Site 2 and Site 3 have moderate organic pollution, and rest of sites have lack of organic pollution. However, necessary precautions and management like control of floating macrophytes density, nutrient loading within these ponds and regular monitoring are needed to check eutrophication and these will support a host of planktonic populations as well as the pisciculture practice. However, intensive long-term studies are important to protect these productive systems from rapid urbanization and industrialization.

Acknowledgements The authors express their deep sense of gratitude to Principal, Bankura Sammilani College, West Bengal, for providing laboratory facilities. The last author thankfully acknowledges University Grants Commission (UGC) (Grant No. (BSR)BL/15-16/0006), Government of India, for Dr. D.S. Kothari Postdoctoral Fellowship.

\section{Compliance with ethical standards}

Conflict of interest The authors declare that they have no conflict of interest.

Open Access This article is distributed under the terms of the Creative Commons Attribution 4.0 International License (http://creativeco mmons.org/licenses/by/4.0/), which permits unrestricted use, distribution, and reproduction in any medium, provided you give appropriate credit to the original author(s) and the source, provide a link to the Creative Commons license, and indicate if changes were made. 
Table 7 Phytoplankton diversity and density (number $\mathrm{mL}^{-1}$ ) in selected seven study sites

\begin{tabular}{|c|c|c|c|c|c|c|c|}
\hline Phytoplankton species & Site 1 & Site 2 & Site 3 & Site 4 & Site 5 & Site 6 & Site 7 \\
\hline \multicolumn{8}{|l|}{ Cyanophyceae } \\
\hline Anabaena circinalis & - & - & - & $42 \pm 6$ & $73.7 \pm 10.3$ & - & $13.3 \pm 5.1$ \\
\hline Aulosira implexa & - & - & - & $22.3 \pm 5.1$ & $20 \pm 5.6$ & - & - \\
\hline Chroococcus limneticus & - & - & - & $8.3 \pm 3.1$ & - & - & - \\
\hline Merismopedia minima & - & - & - & $75 \pm 5.6$ & - & - & $15 \pm 5.6$ \\
\hline Oscillatoria limosa & $60 \pm 6.2$ & - & $70.3 \pm 9.61$ & - & - & $41.7 \pm 10.1$ & - \\
\hline Oscillatoria major & - & - & $45 \pm 19.9$ & $60.3 \pm 8.1$ & - & - & - \\
\hline Spirulina major & - & - & - & - & $7.3 \pm 3.8$ & - & - \\
\hline \multicolumn{8}{|l|}{ Chlorophyceae } \\
\hline Ankistrodesmus falcatus & - & - & - & $24.67 \pm 4.2$ & - & - & - \\
\hline Bulbochaete satigera & - & - & - & - & - & - & $17.3 \pm 0.6$ \\
\hline Chara braunii & - & - & - & - & - & $5.3 \pm 3.5$ & $3.7 \pm 3.1$ \\
\hline Chlorella vulgaris & - & $37 \pm 6$ & - & - & - & - & - \\
\hline Cladophora glomerata & $56.3 \pm 11.1$ & - & - & $28 \pm 4.4$ & - & - & - \\
\hline Closterium parvulum & - & $5.7 \pm 2.31$ & - & - & - & - & $5 \pm 5.3$ \\
\hline Closterium ehrenbergii & - & - & $3.3 \pm 2.1$ & - & - & - & - \\
\hline Coelastrum microporum & $43 \pm 5.2$ & - & - & - & $22 \pm 2.7$ & - & - \\
\hline Coleochaete islamii & - & - & - & - & $3 \pm 2.7$ & - & $3.7 \pm 2.5$ \\
\hline Desmidium baileii & - & - & $24.7 \pm 2.9$ & - & - & - & - \\
\hline Dimorphococcus lunatus & - & $14.3 \pm 3.1$ & - & - & - & - & - \\
\hline Gonium pectorale & - & - & - & $27 \pm 6.6$ & - & - & - \\
\hline Hyalotheca dissiliens & - & - & $15 \pm 4.6$ & - & - & - & - \\
\hline Mougeotia punctata & - & $18.3 \pm 7.5$ & - & $23 \pm 3.6$ & - & - & - \\
\hline Nitella mисronata & - & $4 \pm 2$ & - & - & - & - & $4 \pm 3$ \\
\hline Oedogonium fragile & - & - & $6.3 \pm 1.5$ & - & - & $16.3 \pm 3.1$ & $16.7 \pm 5.1$ \\
\hline Oedogonium aquaticum & - & - & - & - & - & - & $16 \pm 5.6$ \\
\hline Oocystis elliptica & - & - & - & $5 \pm 2.7$ & - & - & - \\
\hline Oocystis pusilla & $5 \pm 3.6$ & - & - & - & $14 \pm 3.5$ & - & - \\
\hline Pediastrum duplex & - & - & - & - & $33.7 \pm 5.7$ & - & - \\
\hline Pediastrum tetras & - & - & - & - & $18.3 \pm 9.7$ & - & - \\
\hline Pleurotaenium trabecula & - & $4.7 \pm 3.1$ & - & - & $4 \pm 3.6$ & - & - \\
\hline Rhizoclonium lapponicum & - & - & - & $19.3 \pm 1.5$ & $13.7 \pm 8.0$ & $33.7 \pm 8.1$ & - \\
\hline Scenedesmus bijugatus & - & $15 \pm 3.6$ & - & - & - & - & - \\
\hline Scenedesmus obliquus & - & $15.3 \pm 4$ & - & - & $18.7 \pm 4.6$ & - & $7.7 \pm 0.6$ \\
\hline Spirogyra gracilis & $44 \pm 6.2$ & - & $23.7 \pm 2.3$ & $24.3 \pm 8$ & $21.7 \pm 5.5$ & $26 \pm 3.6$ & - \\
\hline Spirogyra weberi & - & - & $13.7 \pm 4.2$ & $22.3 \pm 0.6$ & - & - & - \\
\hline Spirogyra maxima & - & - & $26.7 \pm 10.1$ & - & - & - & $19 \pm 5.3$ \\
\hline Tetraedron trigonum & - & - & - & $3 \pm 1$ & $2.3 \pm 2.3$ & - & - \\
\hline \multicolumn{8}{|l|}{ Bacillariophyceae } \\
\hline Cymbella acuta & - & - & $11.7 \pm 4.2$ & - & - & - & $14.7 \pm 8.3$ \\
\hline Eunotia pectinalis & - & $2.7 \pm 1.5$ & - & - & - & - & - \\
\hline Nitzschia amphibia & - & - & - & $3.3 \pm 1.5$ & - & $9.7 \pm 3.2$ & $2.7 \pm 3.1$ \\
\hline Nitzschia sigma & - & $5.3 \pm 2.3$ & $2.67 \pm 1.5$ & - & - & $3.6 \pm 3.1$ & - \\
\hline Synedra acus & $6.3 \pm 2.3$ & - & $5 \pm 2.7$ & $6 \pm 1$ & $3.33 \pm 1.2$ & - & - \\
\hline \multicolumn{8}{|l|}{ Euglenophyceae } \\
\hline Euglena acus & - & - & - & $2.7 \pm 1.6$ & - & - & - \\
\hline Phacus acuminatus & - & - & - & $6.3 \pm 4$ & - & - & - \\
\hline
\end{tabular}




\section{Appendix 1}

See Table 7.

\section{References}

Adhikari S, Roy Goswami A, Mukhopadhyay SK (2017) Diversity of zooplankton in municipal wastewater-contaminated urban pond ecosystems of the lower Gangetic plains. Turk J Zool 141:464-475

Ali MB, Tripathi RD, Rai UN, Pal A, Singh SP (1999) Physico-chemical characteristics and pollution level of lake Nainital (U.P., India): Role of macrophytes and phytoplankton in biomonitoring and phytoremediation of toxic metal ions. Chemosphere 39(12):2171-2182

Badsi H, Ali QH, Loudiki M, Aamiri A (2012) Phytoplankton diversity and community composition along the salinity gradient of the massa estuary. Am J Hum Ecol 1(2):58-64

Chakraborty D, Das SK (2004) Seasonal cycle of phytoplanktons and macrophytes in the river Jalangi. Environ Ecol 22(2):480-481

Chakraborty I, Dutta S, Chakraborty C (2004) Limnology and plankton abundance in selected beels of Nadia district of West Bengal. Environ Ecol 22:576-578

Chattopadhyay C, Banerjee TC (2007) Temporal changes in environmental characteristics and diversity of net phytoplankton in a freshwater lake. Turk J Bot 31(4):287-296

Chiarucci A, Bacaro G, Rocchini D, Scheiner SM (2009) Spatially constrained rarefaction: incorporating the autocorrelated structure of biological communities into sample-based rarefaction. Community Ecol 10(2):209-214

Chouyyok W, Wiacek RJ, Pattamakomsan K, Sangvanich T, Grudzien RM, Fryxell GE, Yantasee W (2010) Phosphate removal by anion binding on functionalized nanoporous sorbents. Environ Sci Technol 44(8):3073-3078

Das D, Keshri JP (2012) Coccal Green algae from Bitang-cho Lake (a high altitude lake in Eastern Himalaya). Indian Hydrobiol 15(2):171-182

Das D, Keshri JP (2013) Desmids of Khechiperi Lake, Sikkim Eastern Himalaya. Algol Stud 143:27-42

Das D, Mustafa G, Keshri JP (2011) Contributions to our knowledge of unicellular and colonial green algae belonging to the orders Volvocales and Tetrasporales (Chlorophyta) of Burdwan, West Bengal, India. J Econ Taxon Bot 35(1):218-223

Das D, Pal S, Palit D (2012) An insight into the physico-chemical characteristics of water and soil along with macrophyte diversity in Kathgola Dighi: a freshwater wetland in Jalpaiguri District, West Bengal. India. J Biodivers Ecol Sci 2(4):216-222

Das D, Pal S, Keshri JP (2015) Environmental determinants of phytoplankton assemblages of a lentic water body of Burdwan, West Bengal, India. Int J Curr Res Rev 7(4):1-7

Desikachary TV (1959) Cyanophyta. Indian Council of Agriculture Research, New Delhi, p 686

EPA (2012) 5.8 Total dissolved solids. In water: monitoring and assessment. http://water.epa.gov/type/rsl/monitoring/vms58.cfm

Flöder S, Sybill J, Gudrun W, Carolyn WB (2010) Dominance and compensatory growth in phytoplankton communities under salinity stress. J Exp Mar Biol Ecol 395:1-2

Ghosh S, Keshri JP (2011) Assessment of phytoplankton diversity and dynamics of a lentic water body of Belur rail station area, with reference to pollution status. Environ Ecol 29(1):232-234

Google Earth Pro V 7.3.0.3832 (2017 October 16) Study sites, Bankura, West Bengal. 23ำ $13^{\prime} 26.64^{\prime \prime} \mathrm{N}-23^{\circ} 14^{\prime} 16.40^{\prime \prime} \mathrm{N}, 87^{\circ}$ $1^{\prime} 54.03^{\prime \prime} \mathrm{E}-87^{\circ} 3^{\prime} 34.66^{\prime \prime E}$. Digital Globe, 2018
Goswami G, Pal S, Palit D (2010) Studies on the physico-chemical characteristics, macrophyte diversity and their economic prospect in Rajmata Dighi: a wetland in Cooch Behar District, West Bengal, India. NeBIO J 1(3):21-26

Hem JD (1985) Study and interpretation of the chemical characteristics of natural water. USGS water-supply paper 2254. http://pubs.usgs. gov/wsp/wsp2254/pdf/wsp2254a.pdf

Husted F (1930) Bacillariophyta (Diatomeae). In Die Süsswasser-Flora Mitteleuropas, Pascher, A. Heft 10, Gustav Fischer, Jena

Hutchinson GE (1961) The paradox of the plankton. Am Nat 95:137-145

Kemker C (2015) Conductivity, salinity and total dissolved solids. Fundamentals of environmental measurements. Fondriest Environmental, Fairborn

Larson CA, Belovsky GE (2013) Salinity and nutrients influence species richness and evenness of phytoplankton communities in microcosm experiments from Great Salt Lake, Utah, USA. J Plank Res 35(5):1154-1166

Liu C, Liu L, Shen H (2010) Seasonal variations of phytoplankton community structure in relation to physico-chemical factors in Lake Baiyangdian, China. Procedia Environ Sci 2:1622-1631

López-Flores R, Quintana XD, Romaní AM, Bañeras L, Ruiz-Rueda O, Compte J, Green AJ, Egozcue JJ (2014) A compositional analysis approach to phytoplankton composition in coastal mediterranean wetlands: influence of salinity and nutrient availability. Estuar Coast Shelf Sci 136:72-81

Miller RL, Bradford WL, Peters NE (1988) Specific conductance: theoretical considerations and application to analytical quality control. In: U.S. geological survey water-supply paper. http://pubs.usgs. gov/wsp/2311/report.pdf

Mohamed AS, Thirumaran G, Arumugam R, Kannan RR, Anantharaman P (2009) Studies of phytoplankton diversity from Agnitheertham and Kothandaramar Koil Coastal Waters, Southeast Coast of India. J Environ Res 59(2):119-124

Mukhopadhyay SK, Ghosh A, Roy S (1997) Primary productivity of phytoplankton in two freshwater bodies at Chinsurah in summer. Geobios 24(1):47-50

Nielsen DL, Brock MA, Rees GN, Baldwin DS (2003) Effects of increasing salinity on freshwater ecosystems in Australia. Aust J Bot 51:655-665

Oso JA, Fagbuaro O (2008) An assessment of the physicochemical properties of a tropical reservoir, Southwestern Nigeria. J Fish Int 3(2):42-45

Pal S, Chattopadhyay B, Mukhopadhyay SK (2013) Variability of carbon content in water and sediment in relation with physico-chemical parameters of East Kolkata Wetland Ecosystem: A Ramsar Site. NeBIO J 4(6):70-75

Pal S, Mondal P, Bhar S, Chattopadhyay B, Mukhopadhyay SK (2014) Oxidative response of wetland macrophytes in response to contaminants of abiotic components of East Kolkata wetland ecosystem. J Limnol Rev 14(2):101-108

Pal S, Chakraborty S, Datta S, Mukhopadhyay SK (2018) Spatio-temporal variations in total carbon content in contaminated surface waters at East Kolkata Wetland Ecosystem, a Ramsar Site. Ecol Engg 110:146-157

Palmer CM (1969) Composite rating of algae tolerating organic pollution. J Phycol 5:78-82

Philipose MT (1967) Chlorococcales. Indian Council for Agricultural Research, New Delhi

Ponmanickam P, Rajagopal T, Rajan MK, Achiraman S, Palanivelu K (2007) Assessment of drinking water quality of Vembakottai reservoir, Virudhunagar district, Tamil Nadu. J Exp Zool India 10(2):485-488

Prescott GW (1962) Algae of the western great lakes area, vol 2. W.M.C. Brown Company Publishers, Dubuque Lowa, p 660 
Quinn GP, Keough MJ (2002) Experimental design and data analysis for biologists. Cambridge University Press, New York

Redden AM, Rukminasari N (2008) Effects of increases in salinity on phytoplankton in the broadwater of the Myall Lakes, NSW, Australia. Hydrobiology 608:87-97

Roy Goswami A, Chattopadhyay B, Datta S, Mukhopadhyay SK (2011) Diversity of plankton in wastewater-fed fishponds of East Calcutta Wetlands with notes on their ecology. Geobios 38:9-16

Roy Goswami A, Aich A, Pal S, Chattopadhyay B, Mukhopadhyay SK (2013) Antioxidant response to oxidative stress in micro-crustaceans thrived in wastewater-fed ponds in East Calcutta Wetland Ecosystem, a Ramsar Site. Toxicol Environ Chem 95(4):627-634

Saravanakumar A, Sesh SJ, Thivakaran GA, Rajkumar M (2008) Benthic macrofaunal assemblage in the arid zone mangroves of Gulf of Kuchchh-Gujarat. J Ocean Univ China 6:33-39

Schmidt LJ (2000) Polynyas, $\mathrm{CO}_{2}$, and diatoms in the Southern Ocean. In: NASA earth observatory. http://earthobservatory.nasa.gov/ Features/Polynyas/

Senthilkumar R, Sivakumar K (2008) Studies on phytoplankton diversity in response to abiotic factors in Veeranam lake in the Cuddalore district of Tamil Nadu. J Environ Biol 29(5):747-752

Sharma RC, Singh N, Chauhan A (2016) The influence of physicochemical parameters on phytoplankton distribution in a head water stream of Garhwal Himalayas: a case study. Egypt J Aquat Res 42:11-21

Shekhar RT, Kiran BR, Puttaiah ET, Shivaraj Y, Mahadevan KM (2008) Phytoplankton as index of water quality with reference to industrial pollution. J Environ Biol 29:233-236
Sridhar R, Thangaradjou T, Senthil KS, Kannan L (2006) Water quality and phytoplankton characteristics in the Palk Bay, southeast coast of India. J Environ Biol 27(3):561-566

Tas B, Gonulol B (2007) An ecologic and taxonomic study on phytoplankton of a shallow lake. Turk J Environ Biol 28:439-445

TerBraak TJF, Prentice IC (1988) A theory of gradient analysis. Adv Ecol Res 18:271-317

Turner WB (1892) The fresh-water algae (Principally Desmidieae) of East India. K Sv Vetensk Acad Handl 25(5):1-187

Wassie AT, Melese AW (2017) Impact of physicochemical parameters on phytoplankton compositions and abundances in Selameko Manmade Reservoir, Debre Tabor, South Gondar, Ethiopia. Appl Water Sci 7:1791-1798

Wehr JD, Sheath RG (2003) Freshwater algae of North America-ecology and classification. Academic Press, San Diego, CA

Wetzel RG (2001) Limnology: lake and river ecosystems, 3rd edn. Academic Press, San Diego

Publisher's Note Springer Nature remains neutral with regard to jurisdictional claims in published maps and institutional affiliations. 